\title{
Some potential biofuel plants for production of biodiesel in semi-arid and arid conditions: $A$ review
}

\author{
Jolly Garg ${ }^{1}$ and Ashwani Kumar ${ }^{2}$ \\ ${ }^{1}$ Department of batany, d.a.k. Degree college, moradabad, India. \\ ${ }^{2}$ Energy plantation demonstration project centre, department of botany, university of Rajasthan, Jaipur 302004. India.
}

Accepted April 11, 2013

\begin{abstract}
In India the demand of petroleum products has significantly increased during the last two decades due to rapid expansion in transport, industrial and agricultural sector. Plants provide source of renewable energy. A number of plants belonging to families Euphorbiaceae, Asclepiadaceae, Apocynaceae, Convolvulaceae etc. posses hydrocarbons. These triterpenoids are hexane extractable and can be converted into biofuel using hydro in their saps and latex. They contain hydrocarbons, which have over $30 \%$ of tri-terpenoids cracking. Screening of various biofuel plants was carried out.
\end{abstract}

Key words: Euphorbiaceae, latex, hydrocarbons, renewable sources of energy.

\section{INTRODUCTION}

Increasing industrialization and unsustainable consumption patterns of natural resources are enhancing the environmental problems due to depletion of resources and energy. The unsustainable use of renewable resources is creating problems to biodiversity environment and human health. Industrial production of hydrocarbon yielding plants as sources of fuel is considered to be one of the best strategies to provide the paradigm to put our society on the path of sustainability.

Solar energy, accumulated under earth in the form of fossil fuels since the inception of life, accounts for more than $97 \%$ of the world consumption of energy of which the share of oil is about $39 \%$. The biomass accounts for $43 \%$ of the total energy supply in the developing countries as compared to only $1 \%$ in the development countries (Hall, 1982). With the present rate of consumption of 65 million barrels of crude oil per day and projected estimates, the present crude reserves may be badly depleted within the next 40 years. The energy costs for extracting the residual crude oil shall far exceed the energy gain after that period (Calvin, 1977).

Also in India, the demand of petroleum products has significantly increased during the last two decades due to rapid expansion in transport, industrial and agricultural sector. Despite the fact that indigenous production of crude oil increased from 6.82 million tonnes between 1971 and 1972 to 28.99 million tonnes between 1984 and 1985, imports also increased from 12.77 million tonnes to 19.73 million tonnes during the corresponding period, thus implying a huge drain of foreign exchange. The demand of petroleum products increased from 19.1 million tonnes in 1970-1971 to 40.50 million tonnes in 1984 and 1985 . This is estimated to touch 57.0 million tonnes in 1990 and 1991 and 92.0 million tonnes by 2000 A.D. This indicates considerable shortage in energy supply during the coming years (Vimal, 1986).

In the third world, biomass is used mainly as fuel wood by over $90 \%$ of the population. The world's total yearly supply of fuel wood, which is more than double in the last 40 years up to 1950 , is estimated to have leveled off at about 1070 million $\mathrm{m}^{3}$ per cent thereafter (Lewis, 1981). Tropical forests in the world are estimated to be vanishing at an annual rate of about 7 million hectares while the corresponding rate for woodlands in the semi- 
arid zones is 4 million hectares (Tebicke, 1985). On steeply sloping terrain receiving substantial rainfall, as well as in arid and semi-arid zones, clear cutting of forests and woodlands is followed by severe water and wind erosion and land degradation.

In India, $68.5 \%$ of the energy used in households is from the firewood and $64.2 \%$ of it is collected from natural sources. The shortfall in fuel production is likely to rise to 137 million tonnes in 2000 A.D. from the present 84 million tonnes (Vimal, 1986). The indiscriminate felling of trees has reduced the forest cover to $23 \%$ against $33 \%$ during the last decade. The annual production of dry dung is of the order of 350 million tonnes from about 240 million cattle, which is capable of generating 70 billion cubic meters of gas annually in biogas processing plants. However, most of the dry dung is used for burning (Murty, 1985).

Source wise, energy consumption in the household sector in the rural areas is as follows: non-commercial sources like fuel wood (68.5\%), animal dung (8.3\%); commercial energy sources like oil (16.9\%), coal (2.3\%), electricity $(0.6 \%)$ and others (3.4\%) (Vimal and Tyagi, 1984).

Energy sources can be broadly divided into three distinct groups: fossil fuels, fissionable nuclear fuels and non-fossil, non-nuclear energy sources. Inspite of their outstanding virtues, fossil fuels have two insurmountable drawbacks. Firstly, these are non-renewable and thus supply of such fuels is either approaching exhaustion or getting more difficult to procure due to transport bottlenecks and steep hike in their price level. Secondly, their continued and increasing use creates environmental problems. Like fossil fuels, fissionable nuclear fuels also suffer from two serious drawbacks. Their supply from relatively cheap sources is drying up even for the most advanced countries. Moreover, the production and use of this source cause a plethora of hazards both to man and his balanced environment.

The non-fossil, non-nuclear energy possibilities fall in three groups: namely, non-solar such as geothermal and tides; indirectly solar such as winds and ocean thermal gradients and directly solar, which among other options includes photosynthesis. All other alternative sources under this category have one or the other practical hurdles in the way of their harnessing energy. Viewed from economic, technological, social, and material factors, they lack the capacity of meeting our future energy needs. Photosynthesis or the photobiological process is a continuous activity, creating organic carbon that burns with less air pollution than fossil fuels. Photosynthesis helps to remove carbon dioxide from the atmosphere and generates oxygen, the life sustaining gas. It thus helps to minimize environmental pollution. During the last hundred years, the concentration of carbon dioxide has significantly increased due to an ever increasing use of fossil fuels. In the last decade alone, it has increased by about $100 \mathrm{ppm}$. This is likely to warm up the upper layers of the oceans and cause a rise in the sea level (Vimal and Tyagi, 1984).

The only appropriate alternative to the socio-economic conditions prevailing in this country is the photosynthetic model of development. It has been the source of an old, reliable and renewable form of energy, now referred to under a new name, biomass. This is relevant even for all developing countries, although its extent and nature may vary from one country to another (Khoshoo, 1984).

Out of the total solar energy on earth $\left(3 \times 10^{24} \mathrm{~J}\right)$, the plant life utilize about $0.1 \%$ annually, leading to an annual net production of $2 \times 10^{11}$ tonnes of organic matter, which has an energy content of $3 \times 10^{12} \mathrm{~J}$ the total annual energy use, however, is of the order of $3 \times 10^{20} \mathrm{~J}$ (Hall, 1982). One of the natural assets of our country is the abundant sunshine. The total solar radiation received in India is about $60 \times 10^{13} \mathrm{MWH}$, with 250 to 300 days of useful sunshine per year in most parts of the country. The daily average direct radiation at places in the central part of the country is 5 to $7 \mathrm{Kwh} / \mathrm{m}^{2}$. There is thus, a vast scope for harvesting solar energy and improvement in photosynthetic efficiency (Dayal, 1984).

The best solar converting machine available today is the green plant which can produced fuel and material on renewable basis (Szego and Kemp, 1973; Calvin, 1976, 1977, 1978a, 1978b, 1979b, 1980, 1983a, 1983a, 1983b, 1984, 1985; Calvin et al., 1981, 1982; Buchanan and Otey, 1979; Buchanan et al., 1978a, 1978b; Vergara and Pimental, 1978; Weisz and Marshall, 1979; Bagby et al., 1980; Hall, 1980; Johnson and Hinman, 1980; Coffey and Halloran, 1981; Lipinsky, 1981; Lipinsky et al., 1980; Tideman and Hawker, 1981; Wang and Huffman, 1981; Khoshoo, 1982; McLaughling et al., 1983; Stewart et al., 1982; Adams and McChesney, 1983; Bhatia and Srivastava, 1983; Hoffman, 1983; Nemethy, 1984 and Vimal, 1986).

Biomass energy is thus, environmentally a very acceptable resource. The wide use of biomass for development offers minimal ecological imbalance and provide means of recycle nutrients and carbon dioxide from the atmosphere (Dayal, 1986; Vimal, 1986).

In India until recently, the energy from biomass came almost entirely from fuel wood, crop and livestock residues. However, in the last few years, attention has been given to the question of energy plantation and energy cropping, specifically for the purpose of providing fuel. Technologies are being developed to convert these sources into traditional forms of commercial energy that is, liquid, solid and gaseous fuels. If the new technologies find wider index acceptance and percolate in the rural areas, energy from biomass can meet $77 \%$ of the total energy needs of the country (Vimal and Tyagi, 1984).

\section{MODERN BIOENERGY TECHNOLOGIES AND BIOFUELS}

Modern bioenergy technologies and biofuels are 
relatively benign from environmental view point and produce very little pollution if burned correctly and completely. The creation of new employment opportunities within the community and particularly in rural areas is one of the major social benefits from the exploitation of biomass for energy, industry and environment. Use of biomass for energy and industry allows a significant quantity of hydrocarbons to be consumed without increasing the $\mathrm{CO}_{2}$ content of the atmosphere and thus makes a positive contribution to the Greenhouse effect and to the problems of "global change" as it occurs in both industrialized and developing countries. Further advantages from utilization of biomass include: liquid fuels produced from biomass contain no sulfur, thus avoiding $\mathrm{SO}_{2}$ emissions and also reducing emission of N0x. Improved agronomic practices and well managed biomass plantations will also provide a basis for environmental improvement by helping to stabilize certain soils, avoiding desertification which is already occurring rapidly in tropical countries.

\section{CALOTROPIS PROCERA}

Calotropis procera carried in arid and semi arid lands which occupy one third of the earth's surface. Indian arid zone occupies an area of about 0.3 million sq. $\mathrm{km}$. $90 \%$ of which about 270,000 sq. $\mathrm{km}$. is confined to north west Indian covering most of Western Rajasthan, part of Gujarat and small portions of Punjab and Haryana. India with its vast expanse of wasteland unsuitable for agricultural production (nearly 180 million ha) could be considered for economically viable production of biofuels.

\section{PRODUCTIVITY}

If 10,000 plants are grown in one ha at $1 \times 1 \mathrm{~m}$ distance and average plant weight is $20 \mathrm{~kg}$ then the fresh biomass produced will be $200,000 \mathrm{~kg} / \mathrm{ha} / \mathrm{annum}$ and the dry biomass will be $40,000 \mathrm{~kg}$ or 40 tonnes/ha/annum $(20 \%$ of fresh wt.). This will yield 4 to 4.8 tonnes / ha/annum maximum biocrude (10-12\%). If the cost of biocrude is Rs. 30/- per $\mathrm{kg}$ then the total value will be Rs. 120,000 . The remaining biomass $(90 \%)$ will be 36 tonnes/ha/annum and if it is Rs. 1/- per $\mathrm{kg}$ then its value will be Rs. 36,000 thus the total amount will be $120,000+36,000=$ Rs. $156,000.00$.

If 5,000 plants are grown in one ha at $2 \times 2 \mathrm{~m}$ distance and average plant weight is $100 \mathrm{~kg}$ then the fresh biomass produced will be $500,000 \mathrm{~kg} / \mathrm{ha} /$ annum and the dry biomass will be $100,000 \mathrm{~kg}$ or 100 tonnes/ha/ annum ( $20 \%$ of fresh wt.). This will yield 10 tonnes/ha/annum maximum biocrude (10\%). If the cost of biocrude is Rs. $30 / \mathrm{kg}^{-1}$ then the total value will be Rs. 300,000 . The remaining biomass (90\%) will be 90 tonnes/ha/annum and if it is Rs. $1 / \mathrm{kg}^{-1}$ then its value will be Rs. 90,000 thus the total amount will be $300,000+90,000=R s, 390,000.00$

\section{BIODIESEL PRODUCTION}

A recent World Bank report concluded that "Energy policies will need to be concerned about the supply and use of biofuels as they are about modern fuels (and) they must support ways to use biofuels more efficiently and in sustainable manner. Although, there is significant volume of biodiesel already produced in Europe there are remaining risks slowing down the further expansion to the target set by the European Commission to reach 5\% market share in transportation fuels by the year 2000". These risks are insecurity in raw material supply and prices, doubts about adequate quality assurance and hesitance for a wider acceptance by the Diesel engine manufacturers, mission marketing strategies for targeting biodiesel differential advantages into specific market niches and last not least missing legal frame conditions similar to clean air act in the USA.

\section{BIOMASS AS POTENTIAL RESOURCES}

Biomass resources are potentially the world's largest and sustainable energy source a renewable resource comprising 220 billion oven dry tones (about $4500 \mathrm{EJ}$ ) of annual primary production. The annual bioenergy potential is about $2900 \mathrm{EJ}$ though only $270 \mathrm{EJ}$ could be considered available on sustainable basis and at competitive prices. Most major energy scenarios recognize bioenergy as an important component in the future world's energy. Projections indicate the biomass energy use to the range of $85 \mathrm{EJ}$ to $215 \mathrm{EJ}$ in 2025 compared to current global energy use of about $400 \mathrm{EJ}$ of which $55 \mathrm{EJ}$ are derived from biomass (Hall and Calle 1998).

\section{SOME IMPORTANT AGRONOMIC ASPECTS FOR CALOTROPIS PROCERA CULTIVATION}

Although Calotropis procera can be germinated throughout the year however the suitable time for sowing of Calotropis procera is May-June. Suitable sowing depth for Calotropis procera is 3 to $4 \mathrm{~cm}$. Calotropis does not require deep tillage. One irrigation should be applied immediately after sowing if there is no rainfall. The intensify of weeds badly affects the plant growth therefore it is prudent to eradicate them. Suitable time for weed erradication is 45 days after sowing. First harvest may be done after three to four months after sowing. Plants may be thinned to have suitable number of plant for per unit area for better plant growth. The suitable time for thinning is after about 45 days after germination. An experiment is in progress to determine the suitable density of plants in per unit area. 
However for developing countries it is important to develop crop plants that grow on wastelands and are able to produce sufficient biocrude at economic costs. The present papers presented the details for strategy for wastland colonization using hydrocarbon yielding plants which could be employed for several developing countries (Kumar 1998).

\section{ACKNOWLEDGEMENT}

The financial support received from Department of Biotechnology, Govt. of India, is gratefully acknowledged.

\section{REFERENCES}

Bhatia VK, Srivastava GS (1983). Introduction screening and cultivation of potential petro-crops and their conversion to petroleum hydrocarbons. Progress Report phase-I . p. 94.

Buchanan RA, Cull IM, Otey FH, Russell CR (1978). Hydrocarbon and rubber producing crops. Evaluation of 100 U.S. Plant species. Econ. Bot. 32:146-153.

Calvin M (1979a). Petroleum plantations for fuel and materials. Bioscience 29:533-537.

Calvin M (1977). Hydrocarbons via photosynthesis. Energy Res. 1:299327.

Calvin M (1978a). Green factories. Chem. Eng. News.50:30-36.

Calvin M (1983b). Oil from plants. Photochem. Photobiol. 37:349-360.

Calvin M (1984). Revewable fuels for the future. J. Appl. Biochem. 6:318.

Calvin M (1976). Photosynthesis as a resource for energy and materials. Photochem. Photobiol. 23:425-444.

Calvin M (1979b). Peteroleum plantations. In Solar Energy : Chemical conversion and storage (Ed.) R.R. Hautalona AB, King, Kutal C Human Press, Clifton NJ.

Calvin M (1980). Hydrocarbons from plants : analytical methods and observations. Die Naturwissen. 67:525-533.

Calvin M (1983a). New sources for fuel and materials. Sci. 219:24-26.

Calvin M (1985). Fuel oils from higher plants. Ann. Proc. Phytochem. Soc. Eur. 26:147-160.

Calvin M, Nemethy EK, RedenbaughK Otvos JW (1982). Plants as a direct source of fuel. Experientia. 38:18.

Calvin M, Nemethy EK, RedenbaughK, Otvos JW(1981). Plants can be direct source of fuel. Petroculture 2:26.

Chopra RW, Nayar SL, Chopra IC (1956). Glossary of Indian medicinal plants. Council of Scientific and Industrial Research, New Delhi, India.

Coffey SG, Halloran GM (1981). Euphorbia perspectives and problems. In. Proc. Natl. Conf. on Fuels from Crops, Melbourne, Australia Sep. pp. $28-29$

Dayal M (1984).Bio-energy; present status and future prospective. In. Proc. Bio-Energy Soc. first convention and symposium '84. (Ed.) R.N. Sharma, O.P. Vimal and P.D. Tyagi, Bio-Energy Soc. of India, New Delhi pp.12-24.

Dayal M (1986). Production and utilization of petro crops. In. Pro. Workshop on petro-crops. Dec. 20-21, Delhi.

Hall DO (1980). Renewable resources, hydrocarbons. Outlook Agric. $10: 246-254$

Hall DO (1982). Food versus fuel, A world problem? In Proc. Energy from biomass and E.C. Conference. (Ed.) Strub, A.P. Chartier and g. Schlesser Applied Science Publishers, London and New York. pp. 43-62.
Hall DO, RosilloCalle F (1998). The role of bioenergy in developing countries. Biomass for energy and industry. Eds. Kpetz et al. pp.5255.

Hinman CW, Hoffman JP, McLaughlin SP, Peoples TR (1980). Hydrocarbon production from arid plant species. In Proc. Ann Meeting of Am. Section Int. Solar Energy Soc. In., Navark DE.

Hoffman JJ (1983). Arid land plants as feedstocks for fuels and chemicals. Plant Sci. 1:95-116.

Johnson JD, Hinman CW (1980). Oils and rubber from arid land plant. Science 208:460-464

Khoshoo TN (1982). Energy from plants: Problems and prospects, Proc. $69^{\text {th }}$ Ind. Sci. Congr. II, 1.

Khoshoo TN(1984). Bio-energy : Scope and limitations. In Proc. BioEnergy Soc. Ist Convention and symposium, '84. (Ed.) R.M. Sharma O.P. Vimal and P.D. Tyagi, Bioenergy Society of India, New Delhi pp. 4-11.

Kumar A (1998). Biomass energy crops of semi-arid regions of India and their energy potential. Biomass for energy and Industry. Eds. Kopetz, H. et al. pp. 345-348.

Lewis CW (1981). Biomass through the ages. Biomass 1:5-15.

Lipinsky ES (1981). Chemicals from biomass : petro-chemicals substitution opitions. Science. 212:1465.

McLaughling SP, Kingsolver BE, Hoffman JJ (1983). Biocrude production in arid lands. Econ. Bot. 37: 150-158.

Murty KS (1985). Bioenergy programme in India. In : Bio-Energy 84. IV. Bio-Energy (Ed.) H. Egneus and A. Ellegard. Elsevier Applied Science, Publishers, London, pp. 385-393.

Nemethy EK (1984). Biochemicals as an energy source. CRC Critic. Rev. Plant Sci. 2:117-129.

Singh NT, Tomer VS (1982). Soil-water plant relationship. In Proc. $12^{\text {th }}$ International Congress of Soil Science: Review of soil research in India, Part I: pp. 3-27.

Stewart GA, Hawker JS, Nix HA, Rawlins WHN, Williams LR (1982). The potential for production of hydrocarbon. Fuel from crops in Australia, A report. p. 86

Szego GC, Kemp CC (1973). Energy forests and fuel plantations. Chem. Tech. 3:275.

Tebicke HL (1985). Bio-Energy research and development in developing countries. In: Bio-Energy 84. V. Bio-Energy in developing countries. Elsevier Applied Science. Publishers, London. pp. 186191.

Tideman J, Hawker JS (1981). The hydrocarbon content of some latex bearing plants in Australia. Search 12:364.

Vergara W, Pimental D (1978). Fuels from Biomass: comparative studies of the potential in five countries USA, Brazil, India, Sudan and Sweden. Adv. Energy Syst. Technol. 1:125.

Vimal OP (1986). Stategies for use of petro-crops. In Proc. workshop on Petro-crops. Dec. 20-21, Delhi.

Vimal OP, Tyagi PD (1984). Energy from biomass. Agricole Publishing Academy, New Delhi. p. 440. 